\title{
THE EMERGENCE OF CYBER LITERATURE: A CHALLENGE TO TEACH LITERATURE FROM TEXT TO HYPERTEXT
}

\author{
Deri Sis Nanda \\ derisisnanda@ubl.ac.id \\ Susanto Susanto \\ susanto@ubl.ac.id \\ Bandar Lampung University, Indonesia
}

\begin{abstract}
In a digital era, people live in a cyberspace that they become part of modern society. The information that they have acquired is from the World Wide Web (WWW). This WWW has become an important medium for people in the world to disseminate information. Because of the technology of Web, cyber literature emerges. This study talks about the emergence of cyber literature which changes the way of reading and teaching in various institutions. It becomes a challenge for people who teach literature because they should leave the printed text and move to the digital text as called hypertext. The existence of cyber literature also drives them change their style to analyze and criticize the work of literature. So, it becomes a challenge for them to teach literature from text to hypertext.
\end{abstract}

Keywords: cyber literature, emergence, text, hypertext, cyberspace, challenge, development.

\section{Introduction}

The influence of technology changes all aspects of people's lives in the world. They become modern society who always get information and do communication in a virtual space. The influence can be seen in work places, homes and teaching institutions. Most of them acquire the information from the World Wide Web (WWW). It is a space for the users to read, write, and access the information with devices connected with the internet. According to Jonassen in his book, Computers in the Classroom: Mindtools for Critical Thinking, this WWW is the greatest and most common usage of hypermedia related to the links connecting information units, and organizing the information via the relationships among the units (Jonassen, 1996). Because of the technology of web, cyber literature emerges. It is a new genre of literature created and presented by means of computer (Koskimaa, 2007). Researchers have been interested in doing the research regarding the cyber literature and they use different terms for cyber literature like cybertext (Aarseth, 1997; Eskelinen, 2012), literary machine (Nelson, 1993), electronic literature (Hayles, 2002), digital literary (Hoover, et al., 2014), and digital literature (Sanz \& Romero, 2007). Then, the discussion on cyber literature may elaborate terminological and aesthetic questions.

The emergence of cyber literature with the use of electronic space as a medium also gives the opportunity for people to read, write and access literary works. In relation to the active production in cyber literature, Neuage (1997) points out that there are many cyber literature communities using the homepage, email, forum, and blogs to publish and promote their literary works. They can write freely without any limitation and upload their works in the WWW. It shows that the works of authors are stored on the internet space and people from all over the world can see it. There is no need to print books with high prices that can limit the spread of literature (Nanda, 2016).

The existence of cyber literature opens the new literary works such as fan fiction (Schulz, 2008). According to Ryan (2013) the computer provides not only a channel of transmission for the texts of fan fiction, it can also become a tool of production. Fan fiction referring to the texts created as 'pseudo-sequels' to a book, comic strip, TV-series or film and 
that are not written by professional authors but by fans. Cyber literature may cover: i) all literary texts such as prose or poetry, anthologies of digitized prose or poetry, online literature magazines and collections of classical texts which are available in the World Wide Web (WWW), ii) non-professional literary texts which are available at the internet and iii) hypertext literature and cybertext in relation to the literary texts of more complex structure. Because of the various literary texts which are available on the internet, it enriches the common views of cyber literature and constructs the new concepts from the literary point of view such as cybertext and hypertext.

The acceptance of cyber literature may give a good sign for literature field itself. Because of the development of the technology, many possibilities could be done by the authors. They can share their literary works without any other limitation. The dissemination of the information from the authors helps people understand about the global culture. It is a breakthrough in cyber literature.

\section{Hypertext: A New Way of Reading Literature}

The emerging field of cyber literature can change the way of reading. People get the exposure for reading more the digital literary texts than the printed ones. Their reading with the internet aids drives them into a different kind of reading. It is because they use hypertext. Hypertext, as Patterson (2000) states, is the electronic linking of text which can be found in the internet. By using the electronic linking of texts, people are experiencing a new way of reading. She adds that by clicking for showing another screen with a new topic, a reader constructs meaning in a different way. It is illustrated in Figure 1.

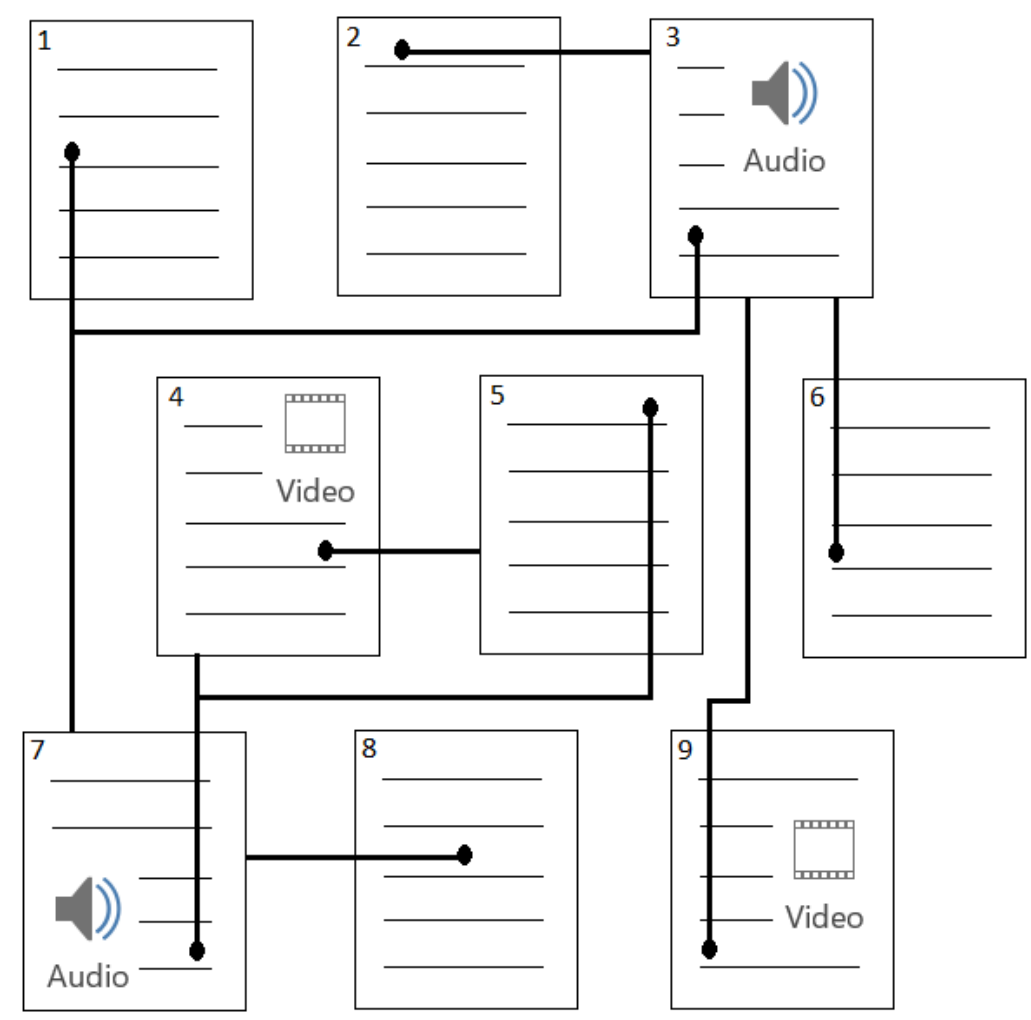

Figure 1: The concept of hypertext in linking various blocks of texts embedded with multimedia works.

Hypertext is primarily text-based and it is characterized by linking various blocks of texts together. It can be embedded with the form of multimedia works combining written 
texts with video clips, music sounds and other media arts. The establishment of this new way of reading literary texts can replace the conventional linearity of literary texts. For an instance, digital literary texts are consumed with their navigational choices (Landow \& Delany, 1991; Landow, 1997; Bolter, 1991).

In addition, Aarseth (1997) and Hayles (2002) assume that hypertext can the source of narrative embodied in cybertext and it needs a new approach to understand its textuality comprehensively. The approach can exploit a hypertextual reading experience with a simple presence of a cursor on a screen. The cursor is a physical means of inserting the reader into the text. It creates a visual reminder that the reader is always present (Landow, 1997; Lanham, 1993).

In order to examine the notion of hypertext, the reader experiences reading with existing of the concrete of the page as a material artifact which can be cut/pasted; redesigned through gutters, margins, and space; and refashioned through material fibers of the page that interact with various paints in various ways of links (Hayles, 2002). Since cyber literature cannot be read in a conventional way, the way of reading has changed. The significant change deeply affects the reader and makes him/her fast. Reading cyber literature therefore needs an additional effort to traverse the text.

\section{The Challenge of Teaching Literature from Text to Hypertext}

Cyber literature can have educational and pedagogical impacts when it incorporates into an existing curricula. Thus, teaching literature from text to hypertext can be challenging. To face the possible challenge, educational innovations are required to accommodate the solution for the educational purposes. One of the strategies is through role-based online discussion for teaching literature, which is called as 'The Ivanhoe Game' approach (Koskimaa, 2007). In this approach, each student is assigned a certain character based on the literary works and they should find the information about the characters. They should be able to conduct online discussion impersonating their assigned characters.

Another strategy is using literary blogs which offer a huge potential for literary education. Further, a teacher can also develop a new design unit in the blog. In designing a unit to teach literature in the form of hypertext, it is necessary to work with the literary hypertext production. The WWW as the media for literary hypertext needs some broad and various formats for the student to write their own idea, criticize and make a comment on cyber literature. Figure 2 shows the Haiku poem in the form of hypertext and there are some menus for the students to give their comments regarding the literary works. 
nanda cyber literature

make your dream come true

\section{HAIKU POEMS ON YOUR DAY}

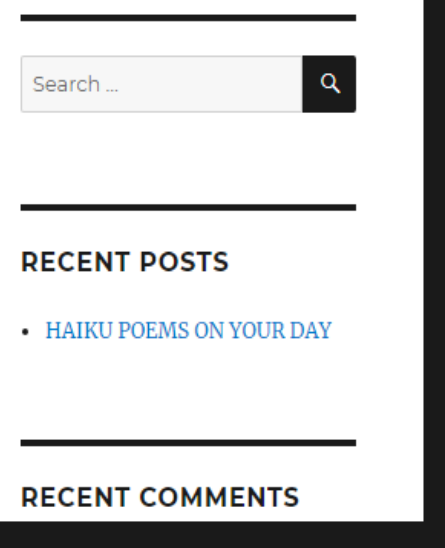

Figure 2: An example of cyber literature

Basically, providing the menu for comments may facilitate a new strategy, i.e. readerwriter interactivity (Jauss, 1982) to appreciate the literary works. It can develop the focus on distributing attention which is accessed by other readers and it may require the responses traced digitally in the blog. The interaction can drive the consumers of the literary work contemplate and immerse in the text. Besides, a new idea may develop by sharing and commenting on the text.

\section{Conclusion}

In a cyberspace, literary works in the digitized forms are consumed along with those in the printed ones. And, the development of web technology makes people have the different way of reading literature which is not based on the conventional linearity but navigational one instead. Using the internet aids, navigational linearity drives into a different kind of reading, i.e. hypertext, having the electronic linking of the text. Clicking on showing the new screen is one of the experiences that the readers acquire from reading hypertext literature to get more information. Thus, the emergence of cyber literature with hypertext as media encourages the access of literature as the mode of expression. For educators who teach literature in the digital world, it is challenging and it requires educational innovations, e.g. conducting role-based online discussion on cyber literary works and using literary blogs with reader-writer interactivity. 


\section{References}

Aarseth, E. (1997). Cybertext. Baltimore, MD: Johns Hopkins University Press.

Bolter, D.J. (1991). Writing Space: The Computer, Hypertext, and the History of Writing. Hillsdale, NJ: Lawrence Erlbaum Associates,

Douglas, J.Y. (1994). "How Do I Stop This Thing?" Closure and Indeterminacy in Interactive Narratives. In Landow, G.P. (Ed.). Hyper/Text/Theory. Baltimore \& London: Johns Hopkins University Press, 159-188.

Eskelinen, M. (2012). Cybertext Poetics: International Texts in Critical Media Aesthetics. New York: Continuum.

Hayles, N.K. (2002). Writing Machines. Cambridge, MA and London: The MIT Press. Hoover, D.L., Culpeper, J., \& O’Halloran, K. (2014). Digital Literary Studies: Corpus Approaches to Poetry, Prose, and Drama. New York: Routledge.

Jauss, H.R. (1982). Toward an Aesthetic of Reception. Minneapolis: University of Minnesota Press. Jonassen, D.H. (1996). Computers in the classroom: Mindtools for critical thinking. Columbus, OH: Merrill/Prentice-Hall. Koskimaa, R. (2007). The challenge of cybertext: teaching literature in the digital world. UOC Papers. Iss. 4. UOC. [Date accessed: 25/07/2018]. Retrieved from http://www.uoc.edu/uocpapers/4/dt/eng/koskimaa.pdf

Landow, G.P., \& Delany, P. (Eds.) (1991). Hypermedia and Literary Studies. Cambridge: Massachusetts Institute of Technology Press.

Landow, G.P. (1997). Hypertext 2.0: The Convergence of Contemporary Critical Theory and Technology. Baltimore:Johns Hopkins UP.

Lanham, R.A. (1993). The Electronic Word: Democracy, Technology, and the Arts. Chicago: The University of Chicago Press.

Nanda, D. S. (2016, May). Fostering the Use of Drama for English Language Learners in the Efl Classroom. In International Conference on Education and Language (ICEL) (p. 7).

Nelson, T. (1993). Literary Machines. Sausalitu, CA: Mindful Press.

Neuage, T. (1997). Influence of the World Wide Web on literature. Victoria: Deakin University Press.

Patterson, N.G. (2000). The English class Hypertext and the Changing Roles of Readers. English Journal [Date accessed: 25/07/2018]. Retrieved from http://homepages.gac.edu/ mkoomen/edu241/hypertext.pdf

Ryan, M.L. (2013). Fictional Worlds in the Digital Age. In Siemens, R. \& Schreibman, S. (Eds.), A Companion to Digital Literary Studies. West Sussex. UK: Blackwell Publishing Ltd.

Sanz, A., \& Romero, D. (2007). Literatures in the Digital Era: Theory and Praxis. Newcastle: Cambridge Scholars Publishing. Schulz, N. (2008). "Fan Fiction Literature". Encyclopadia Britannica. Retrieved on July 24, 2018. 